\title{
The use of serine protease from Yarrowia lipolytica yeast in the production of biopeptides from denatured egg white proteins
}

\author{
Marta Pokora', Aleksandra Zambrowicz ${ }^{1 凶}$, Agnieszka Zabłocka², Anna Dabrowska', Marek \\ Szołtysik', Konrad Babij', Ewelina Eckert³, Tadeusz Trziszka and Józefa Chrzanowska \\ 1Department of Animal Products Technology and Quality Management, Wroclaw University of Environmental and Life Sciences, Wrocław, Po- \\ land: 2 Department of Immunochemistry, Hirszfeld Institute of Immunology and Experimental Therapy, Polish Academy of Sciences, Wrocław, \\ Poland; '3Department of Agricultural, Food and Nutritional Science, University of Alberta, 410 Agriculture/ Forestry Centre, Edmonton, AB T6G \\ 2P5, Canada
}

\begin{abstract}
Deriving non-conventional enzymes from cheaper sources than those used for commercially available enzymes may result in the production of hydrolysates with beneficial features, while drastically reducing the cost of hydrolysis. This is especially significant for enzymatic hydrolysis as a method of protein waste utilization. We have previously described the ability of non-commercial serine protease from Yarrowia lipolytica yeast to produce/release bioactive peptides from egg white protein by-products (EP). The enzymatic hydrolysis of EP was carried out for $24 \mathrm{~h}$ using the serine protease at an enzyme: substrate ratio of 1:30 (w/w). The obtained hydrolysate was characterized by protein degradation of $38 \%$ and also exhibited an antioxidant and cytokine-inducing activity. The isolation procedure (ultrafiltration and RPHPLC) of bioactive peptides from the EP hydrolysate provided peptide fractions with significant antioxidant and ACE inhibitory activities. Three homogeneous and three heterogeneous peptide fractions were identified using MALDI-TOF/MS and the Mascot Search Results database. The peptides, mainly derived from ovalbumin, were composed of 2-19 amino-acid residues. We have thus demonstrated a novel ability of serine protease from $Y$. lipolytica to release biopeptides from an EP byproduct.
\end{abstract}

Key words: Yarrowia lipolytica, serine protease, bioactive peptide, antioxidant, ACE-inhibitor

Received: 12 May, 2016; revised: 29 September, 2016; accepted: 17 October, 2016; available on-line: 07 April, 2017

e-mail: aleksandra.zambrowicz@up.wroc.pl

Abbreviations: ANOVA, analysis of variance; $A C E$, angiotensin converting enzyme; $A E P$, alkaline extracellular protease; $\mathrm{DH}$, degree of hydrolysis; DPPH, 1,1-diphenyl-2-picrylhydrazyl; EP, egg white protein by-product; $\mathrm{E}: \mathrm{S}$, enzyme: substrate; ELISA, enzyme-linked immunosorbent assay; FRAP, ferric reducing antioxidant power; $\mathrm{w} / \mathrm{w}$ weight/weight; HHL, hippuryl-His-Leu; GRAS, generally recognized as safe; IL, interleukin; MALDI-TOF/MS, matrix-assisted laser desorption/ionization-time-of-flight mass spectrometry; LP, lipopolysaccharide; RC, regenerated cellulose; RP-HPLC, reversed-phase highperformance liquid chromatography; eq, equivalent; RPMI-1640 medium, RPMI 1640 medium was developed at Roswell Park Memorial Institute; TFA, trifluoroacetic acid; WPC, whey protein concentrate; YM, yeast-maltose

\section{INTRODUCTION}

Proteases are one of the most important groups of enzymes produced on an industrial scale, constituting $60 \%$ of the global market of hydrolytic enzymes (Dhurway et al., 2011; Rohrbach et al., 1981; Ray, 2012). They are widely used in the production of foods, nutraceuti- cals, pharmaceuticals, cosmetics, detergents, as well as in the leather and textile industries, and in waste processing (Bagewadi et al., 2011, Vasantha et al., 2012; Vermelho et al., 2012; Sathyavrathan et al., 2013). The use of proteases in industrial processes depends on their substrate specificity, preference for the position of the hydrolyzed peptide bond, the types of substances inhibiting the activity of the enzyme, as well as stability across a wide range of temperature and $\mathrm{pH}$. One of the most important factors is their cost, dependent on the availability of sources and the procedure of isolation (Srinu Babu et al., 2007).

In the food industry, where they play a particularly important role, proteases must be approved for consumption and - in the case of microbial enzymes - cannot be derived from pathogenic microorganisms. Other important safety issues include their toxicological properties, e.g. the absence of impurities such as mycotoxins and antibiotics (Schaafsma, 2009).

Microorganisms serve as the preferred source of proteases due to their rapid growth, the limited space required for their cultivation, and the possibility of easy genetic manipulation to generate new enzymes with altered properties that suit various applications. Many microorganisms secrete proteases into their external environment in order to degrade proteins. Products of this process are then used as nitrogen sources for cell growth. Extracellular enzymes are attractive for isolation procedures, especially on an industrial scale, because such processes do not require complicated technological operations to obtain the enzyme product (Carr, 2002).

$Y$. lipolytica yeasts possess a high ability to synthesize extracellular proteolytic enzymes. As non-pathogenic organisms, they are generally recognized as safe (GRAS) (Nel et al., 2001), and are present in many food products, mainly dairy products such as cheese, yogurt, and kefir, as well as in sausages, shrimp salads, and soy sauces (Guerzoni et al., 1009). Y. lipolytica species belong to a group of non-conventional yeasts with unique physiological features including the ability to assimilate organic compounds. Y. lipolytica can exploit glucose, alcohols, acetic acid, and hydrophobic substrates such as fatty acids or alkanes (Dominguez et al., 2000). Depending on cultivation conditions and composition of the substrate, $Y$. lipolytica yeasts reveal different potentials to secrete extracellular proteases. The main factor regulating the expression of a specific enzyme is the $\mathrm{pH}$ of the external environment. During growth at a $\mathrm{pH}$ above 7.5, serine protease (alkaline extracellular protease - AEP) is expressed (Glover et al., 1997). This enzyme belongs to 
the family of subtilisins and has a molecular weight of approximately $30.559 \mathrm{kDa}$; its sequence is comprised of 297 amino acids. The active site consists of the Asp200, His231, and Ser397 residues, while the Asn292 and Asn330 residues are potential sites of $\mathrm{N}$-glycosylation. This enzyme displays a caseinolytic activity under optimum conditions of $\mathrm{pH} 9.0$ and temperature of $40^{\circ} \mathrm{C}$. It also demonstrates an esterase activity towards synthetic substrates containing arginine, lysine, or tyrosine, which it degrades optimally at $\mathrm{pH}$ 8.0. The enzyme is stable in a 5.0 to $9.0 \mathrm{pH}$ range, and in the presence of calcium ions (Ogrydziak et al., 2012; 1998).

Recently, proteolytic enzymes have found a wide range of other biotechnological applications, such as bioactive peptide generation, as the result of a precursor protein hydrolysis. The particular researchers' interest in biopeptide production is related to their high therapeutic potential resulting from a broad spectrum of in vivo activities, including antioxidant, antibacterial, antihypertensive, immunomodulatory, as well as opiate functions (Zambrowicz et al., 2015b).

Diseases, such as cardiovascular diseases (including hypertension), tumor, obesity, type 2-diabetes or chronic inflammation represent significant health problems worldwide. The role of reactive oxygen species (ROS) in pathogenesis of these diseases is commonly known. The aforementioned dependencies between their etiologies indicate the special importance of multifunctional peptides: their combined antioxidant, ACE-inhibitory and cytokine inducing activity would make a useful peptide preparation for the control and prevention of the so-called civilization diseases (Zambrowicz et al., 2015b; Booth et al, 2012).

The properties of the peptides depend on the nature of the precursor protein, specificity of the protease used and the hydrolysis conditions (the enzyme / substrate ratio, temperature, $\mathrm{pH}$, time). Therefore, industrial demand for proteases with appropriate specificity and stability continues to motivate the search for new sources.

The work presented here reports on the potential application of a non-commercial proteolytic enzyme from the $Y$. lipolytica JII1c strain to produce biologically active peptides from a hen egg-white protein by-product following lysozyme and cystatin isolation.

\section{MATERIALS AND METHODS}

Microorganism. Y. lipolytica JII1c used in this study originated from the yeast culture collection of the Department of Biotechnology and Food Microbiology, Wrocław University of Environmental and Life Sciences in Poland.

Enzyme preparation. Preparation of the serine protease of $Y$. lipolytica was obtained from a submerged culture of yeast in a mineral-organic medium at $\mathrm{pH} 7.5$. Biosynthesis of the enzymes was carried out at $28^{\circ} \mathrm{C}$ in $300 \mathrm{~mL}$ volumetric flasks containing $50 \mathrm{~mL}$ of the production medium composed of $(\mathrm{g} / \mathrm{L})$ : yeast extract (1.7), isoelectric casein (4.0), fatty acids - a by-product of rapeseed oil refining (10.0), $\mathrm{KH}_{2} \mathrm{PO}_{4}(0.5), \mathrm{MgSO}_{4} \times 7$ $\mathrm{H}_{2} \mathrm{O}(0.25), \mathrm{NH}_{4} \mathrm{Cl}(1.0)$. Inoculum cultures were carried out for 24 hours at $28^{\circ} \mathrm{C}$ in $\mathrm{YM}$ medium, containing $(\mathrm{g} / \mathrm{L})$ : yeast extract (3.0), maltose extract (3.0), bactopeptone (5.0), glucose (10.0), and agar (20.0). All of the cultures were cultivated for $24 \mathrm{~h}$. After cultivation, the biomass was centrifuged at $5000 \times \mathrm{g}$ for 15 minutes at $4^{\circ} \mathrm{C}$. The resulting supernatant was concentrated and purified at $4^{\circ} \mathrm{C}$ using a set of Amicon Bioseparations filtra- tion membranes of regenerated cellulose (RC) (Millipore) with a nominal cut-off of $10 \mathrm{kDa}$.

Determination of protein content. Protein content was determined by the method described by Lowry et al. (1951).

Determination of proteolytic activity. Enzymatic activity was measured in a reaction with $1 \%$ casein $(\mathrm{BDH}$, Ltd. England) and ovalbumin (Sigma) as substrates, at $\mathrm{pH} 7.5$, according to the procedure described previously (Pokora et al., 2010).

EP - egg white protein preparation. EP was obtained in our laboratory as a by-product of lysozyme and cystatin isolation, according to the method of Sokołowska et al. (2007).

Enzymatic hydrolysis. EP hydrolysis was carried out according to Zambrowicz et al. (2015a), with the protease from $Y$. lipolytica at an E:S ratio of 1:30 (w: w), for 24 hours.

Degree of hydrolysis. The degree of hydrolysis (DH) (\%) was measured by determination of a trichloroacetic acid soluble protein fraction (Silvestre, 1996).

Reversed-phase high-performance liquid chromatography (RP-HPLC). Peptide separation was performed by RP-HPLC with an Agilent 1100 Series system using a Zorbax SemiPrep XDB-C ${ }_{18}(5 \mu \mathrm{m} ; 9.4 \times 250 \mathrm{~mm})$ and Zorbax XDB-C1 $1_{8}$ Agilent $(50 \times 1.8 \mathrm{~mm})$ columns, at $\mathrm{T}=30^{\circ} \mathrm{C}$. The mobile phase $\mathrm{A}$ was $0.1 \% \mathrm{TFA}$ (Fluka) in water, and the mobile phase $\mathrm{B}$ was $0.1 \%$ TFA in acetonitrile (LabScan). Other operation conditions were varied; hydrolysate: flow rate $2 \mathrm{~mL} / \mathrm{min}$, gradient: from the fifth minute of analysis $1 \% \mathrm{~B} / \mathrm{min}$; fraction 3 : flow rate: $1 \mathrm{~mL} / \mathrm{min}$, gradient: from the third minute of analysis $4 \% \mathrm{~B} / \mathrm{min}$. The eluents were detected at $230 \mathrm{~nm}$.

DPPH free radical scavenging activity. The antioxidant activities of the obtained hydrolysate and peptide fractions were determined by the radical scavenging effect on stable 1,1-diphenyl-2-picrylhydrazyl (DPPH (Sigma, D21140-0)) by the method described by Yen and Chen (1995) and modified by Zambrowicz et al. (2015 a).

Ferric Reducing Antioxidant Power (FRAP). The antioxidant capacity of the hydrolysate/peptide fractions was determined by the FRAP method according to Benzie and Strain (1996). The concentration of Fe (II) was determined using a standard curve for known Fe (II) concentrations $(0-500 \mu \mathrm{g} / \mathrm{ml} \mathrm{FeSO}$ ). The results obtained are shown as $\mu \mathrm{g} \mathrm{Fe} \mathrm{Fe}^{2+} / \mathrm{mg}$ protein.

Fe (II) ion chelation activity. The ability to chelate the Fe (II) ions by the hydrolysate/peptide fractions was evaluated by the method of $\mathrm{Xu}$ et al. (2007). Known concentrations of $\mathrm{FeCl}_{2}(0-20 \mu \mathrm{g})$ were used to make a standard curve. The ability to chelate iron ions was expressed as $\mu \mathrm{g} \mathrm{Fe}^{2+} / \mathrm{mg}$ protein.

Determination of ACE-inhibitory activity. The ACE inhibitory activity of the hydrolysate and peptide fractions was measured spectrophotometrically according to Miquel et al. (2004). A hydrolysate solution (40 $\mu \mathrm{L})$ mixed with a Hippuryl-His-Leu (HHL) (Sigma, H4884) solution was pre-incubated at $37^{\circ} \mathrm{C}$ for $5 \mathrm{~min}$, and the reaction was initiated by adding $20 \mu \mathrm{L}(2 \mathrm{mU})$ of the ACE solution (EC 3.4.15.1; from rabbit lung, Sigma, A6778) and incubated at the same temperature. After 30 min, the enzymatic reaction was halted by the addition of $150 \mu \mathrm{L}$ of $1 \mathrm{M} \mathrm{HCl}$. The liberated hippuric acid was measured at $\lambda=228 \mathrm{~nm}$. The inhibition activity was calculated using the following equation:

Inhibition activity $(\%)=[(\mathrm{A}-\mathrm{B}) / \mathrm{A}] \times 100 \%$

where $\mathrm{A}$ is the reaction blank where the mixture contained the same volume of the buffer solution instead 
of the ACE inhibitor sample; $B$ is the reaction in the presence of both $\mathrm{ACE}$ and its inhibitor. The $\mathrm{IC}_{50}$ value was estimated from a dose response curve of an inhibitor versus the ACE activity.

Cytokine induction in human whole blood cell cultures. Blood samples obtained from healthy donors were collected into sterile syringes containing $10 \mathrm{U} / \mathrm{mL}$ of heparin. Within 2 hours of collection, the blood was diluted 10-fold with RPMI-1640 medium supplemented with $100 \mathrm{U} / \mathrm{mL}$ penicillin, $100 \mu \mathrm{g} / \mathrm{mL}$ streptomycin, and 3\% L-glutamine. One $\mathrm{ml}$ portions of the blood cell suspensions were distributed into 48 -well tissue culture plates. The examined inductor $(100 \mu \mathrm{g})$ was added to $1 \mathrm{~mL}$ RPMI medium. Lipopolysaccharide from E. coli (LP; $4 \mu \mathrm{g} / \mathrm{mL}$ ) was used as a positive control. The untreated blood samples were used as a negative control to measure the spontaneous cytokine release. Blood samples were incubated for 22 hours at $37^{\circ} \mathrm{C}$ in $5 \% \mathrm{CO}_{2}$. After incubation, the supernatants were collected and the levels of IL- 6 and IL-10 cytokines were determined by ELISA, using commercially available BD OptEIA ${ }^{\mathrm{TM}}$ sets according to the procedure recommended by the manufacturer (Pharmingen, USA).

Molecular weight and sequence of peptides. The molecular weights and sequences of peptide fractions obtained by RP-HPLC were performed using MALDI-ToF analysis UltrafleX-treme apparatus (Bruker Daltonics, Germany) in a positive ion mode. All of the samples were dissolved in $1 \mathrm{ml} \mathrm{60 \%}$ acetonitrile, centrifuged, evaporated and then dissolved again in $60 \mu \mathrm{L}$ of $60 \%$ acetonitrile. 40 $\mu \mathrm{L}$ of this solution was evaporated and then dissolved in $10 \mu \mathrm{L}$ of $50 \%(\mathrm{v} / \mathrm{v})$ acetonitrile. $0.5 \mu \mathrm{L}$ of peptide solution was mixed with $0.5 \mu \mathrm{L}$ of alpha-cyano-4-hydroxycinnamic acid, pipetted onto a steel plate and evaporated to dryness. The MS and MS/MS spectra were collected and processed using FlexControl, FlexAnalysis, BioTools as well as ProteinScape software (Bruker Daltonics, Germany), while protein sequences were identified using a MASCOT server (MS) (Matrix Science, USA) and the UniProtKB/SwissProt protein sequences database (version 25.10.2012, European Bioinformatics Institute, United Kingdom). Taxonomic search was restricted to Gallus gallus, taking into account the possible modifications of polypeptide chains resulting from the oxidation of methionine. No restrictions concerning peptidase specificity during the peptide processing was declared.

Statistical analysis. Experimental hydrolysis was carried out in two independent batches. All analyses of the hydrolysates, as well as the peptide fractions, were done in triplicate for each batch. The data obtained were subjected to multi-factor variance analysis (ANOVA), followed by a Duncan multiple range test to determine the significant difference between samples at $p<0.05$ using Statistica v. 9.0 software.

\section{RESULTS AND DISCUSSION}

Due to its excellent proteolytic properties as well as an easy and cheap process of production, non-commercial serine protease from Y. lipolytica JII1c yeast was used to degrade the denatured EP left as a by-product following the isolation of lysozyme and cystatin, in order to obtain hydrolysates exhibiting biological activity. Native egg white proteins, especially ovalbumin, are known as a good source of biopeptides, and are released by the hydrolysis process conducted with digestive proteases (Miguel et al., 2004; Dávalos et al., 2004; Fujita et al., 2000).
$Y$. lipolytica serine protease is a non-commercial enzyme preparation obtained in our laboratory from a culture broth of yeast cultivated for $48 \mathrm{~h}$. After culturing and centrifugation, the supernatant was ultrafiltered on a cellulosic membrane (cut-off $10 \mathrm{kDa}$ ). As a result of this process, the protease has been purified by 1.4 fold with $85 \%$ recovery. Its activity was measured toward protein standards, such as casein and ovalbumin. It appeared that this protease exhibited a 2 -fold higher proteolytic activity toward casein $(713 \mathrm{U} / \mathrm{mg})$ than toward ovalbu$\min (350 \mathrm{U} / \mathrm{mg})$.

The degradation process of EP was conducted for 24 hours with $Y$. lipolytica serine protease added to the reaction mixture at a dose of $E: S=1: 30$ (w/w). The obtained hydrolysate of EP was characterized by protein degradation (DH) of $38 \%$.

Due to its wide biochemical predispositions, the possibility of applications of $Y$. lipolytica in the biotechnology and food industries has been intensively tested; for example, as factors accelerating cheese ripening (Rywińska et al., 2013; Gardini et al., 2006; Zinjarde, 2014). Still, there is little information on generating bioactive peptides by hydrolysis of food proteins with this enzyme. Therefore, in the research presented here we tested the biological activities of EP hydrolysates and the isolated peptides. The attractiveness of serine protease obtained using $Y$. lipolytica was demonstrated in the evaluation of the antioxidant and ACE inhibitory (for selected peptide fractions) activities of the EP hydrolysates. A high ability to chelate iron (II) at $688.5 \mu \mathrm{g} \mathrm{Fe} \mathrm{Fe}^{2+} / \mathrm{mg}$ was demonstrated, with a reducing power, measured as ferric to ferrous ion reduction ability, of $35.3 \mu \mathrm{g} \mathrm{Fe} \mathrm{Fe}^{2+} / \mathrm{mg}$. A noticeable free radical scavenging activity $(0.21 \mu \mathrm{M}$ Trolox eq $/ \mathrm{mg})$ was also observed (Table 2).

Strong proteolytic properties toward milk proteins, including casein and whey proteins, have been demonstrated in a few earlier publications. Babij et al., (2013), who reported that $\alpha$-lactoalbumin, WPC-50 preparation and $\beta$-lactoglobulin can be hydrolysed by $Y$. lipolytica protease with different efficacy to a DH of $18 \%, 23 \%$ and $39 \%$, respectively. They also confirmed in a further work the high ability of this protease to release peptides with antioxidant activities. Degradation of WPC- 80 preparations led to hydrolysates with significant DPPH free radical scavenging activity $\left(0.81 \mu \mathrm{M}\right.$ Trolox $_{\mathrm{eq}} / \mathrm{mg}$ ) (Babij et al., 2014). However, among the milk proteins, casein was the most susceptible to degradation with this protease and after 24 hours hydrolysis DH reached a level of $66 \%$. The obtained products displayed almost the same level of ferric reducing power $\left(39.0 \mu \mathrm{g} \mathrm{Fe} \mathrm{Fe}^{2+} / \mathrm{mg}\right)$, as in the present study. Interestingly, casein was a better source of peptides than egg yolk protein byproduct, having chelating $\left(1559.0 \mu \mathrm{g} \mathrm{Fe} \mathrm{Fe}^{2+} / \mathrm{mg}\right)$ and free radical scavenging activities $\left(0.86 \mu \mathrm{M}\right.$ Trolox $\left._{\mathrm{eq}} / \mathrm{mg}\right)$ released by the participation of serine protease from Y. lipolytica (Szołtysik et al.,

Table 1. Induction of IL-6 an IL 10 by human whole blood cells in response to EP.

$1 \mathrm{ml}$ portions of human whole blood cells were incubated at $37^{\circ} \mathrm{C}$ for 22 hours in the presence of the analyzed samples $(1-100 \mu \mathrm{g} /$ $\mathrm{ml})$. Lipopolysaccharide (LP) $(4 \mu \mathrm{g})$ was used as a positive control where cells were incubated in the absence of inducers. Supernatants were harvested and analyzed for IL-6 levels by ELISA, as described in Materials and Methods.

\begin{tabular}{lll}
\hline Sample & $\mathrm{IL}-6[\mathrm{pg} / \mathrm{ml}]$ & $\mathrm{IL}-10[\mathrm{pg} / \mathrm{ml}]$ \\
\hline Control & 0 & 0 \\
\hdashline LP & $<1000 \pm 50$ & $361 \pm 110$ \\
\hline EP hydrolyzate & $540 \pm 27$ & $342 \pm 262$ \\
\hline
\end{tabular}


Table 2. The antioxidant activity of the fractions obtained by RP-HPLC separation of the EP hydrolysate obtained with the use of Yarrowia lipolytica serine protease.

The data shown in the table are means (mean \pm S.D., $n=3$ ). The mean values marked in lower case letters in the same column are significantly different at $p \leq 0.05$.

\begin{tabular}{|c|c|c|c|}
\hline $\begin{array}{l}\text { Fraction } \\
\text { number }\end{array}$ & $\begin{array}{l}\text { DPPH } \\
{\left[\mu \mathrm{M} \text { Trolox }_{\mathrm{eq}} / \mathrm{mg}\right]}\end{array}$ & $\begin{array}{l}\text { FRAP } \\
{\left[\mu \mathrm{g} \mathrm{Fe}{ }^{3+} / \mathrm{mg}\right]}\end{array}$ & $\begin{array}{l}\text { Fe (II) chelating } \\
{\left[\mu \mathrm{g} \mathrm{Fe} \mathrm{Fe}^{2+} / \mathrm{mg}\right]}\end{array}$ \\
\hline hydrolysate & 0.21 & 35.3 & 688.5 \\
\hline 1 & $0.04^{c}$ & $8.05^{h}$ & $44.88^{c}$ \\
\hline 2 & $0.02^{a}$ & $4.21^{c}$ & $25.43^{a}$ \\
\hline 3 & $0.16^{f}$ & $12.22^{i}$ & $111.99^{f}$ \\
\hline 4 & $0.04^{c}$ & $12.48^{i}$ & $77.70^{e}$ \\
\hline 5 & $0.06^{e}$ & $13.62^{j}$ & $74.84^{e}$ \\
\hline 6 & $0.04^{c}$ & $6.31^{\text {ef }}$ & $55.16^{d}$ \\
\hline 7 & $0.03^{b}$ & $5.65^{\text {de }}$ & $45.72^{c}$ \\
\hline 8 & $0.02^{a}$ & $2.92^{b}$ & $36.06^{b}$ \\
\hline 9 & $0.02^{a}$ & $3.41^{b}$ & $21.73^{a}$ \\
\hline 10 & $0.02^{a}$ & $2.09^{a}$ & $24.92^{\mathrm{a}}$ \\
\hline 11 & $0.02^{\mathrm{a}}$ & $5.60^{d}$ & $46.94^{c}$ \\
\hline 12 & $0.04^{c}$ & $6.52^{f}$ & $56.80^{d}$ \\
\hline 13 & $0.03^{b}$ & $5.13^{d}$ & $206.96^{h}$ \\
\hline 14 & $0.05^{d}$ & $7.18^{g}$ & $120.52^{g}$ \\
\hline 15 & $0.04 c$ & 7.47gh & $80.82^{e}$ \\
\hline
\end{tabular}

2012). However, DH - which was 1.7 fold higher for the casein hydrolysate - may be a factor influencing the level of antioxidant activity, as this depends not only on the substrate and the degree of hydrolysis, but also on the type of the enzyme applied in the process.

On the other hand, serine protease from $Y$. lipolytica was characterized by a lower ability to hydrolyze the EP preparation than other microbial proteases, such as Neutrase from Bacillus amyloliquefaciens and an Aspergillus melleus protease. These proteases, applied at a dose of $10 \mathrm{U}$ per $\mathrm{mg}$ of EP, resulted in a DH after $24 \mathrm{~h}$ reaction of nearly $75 \%$ and $60 \%$, respectively. The degradation of EP with the use of Neutrase and protease from $A$. melleus led to hydrolysates with positive ferric reducing and ferric chelating properties, 21.0 and $5.9 \mu \mathrm{g} \mathrm{Fe} \mathrm{F}^{2+} / \mathrm{mg}$, and 397.0 and 278.1 $\mu \mathrm{g} \mathrm{Fe} \mathrm{Fe}^{2+} / \mathrm{mg}$, respectively (Zambrowicz et al., 2013). The results indicate that serine protease from $Y$. lipolytica is characterized by excellent properties for releasing antioxidant peptides from EP in comparison to the commercially available microbial enzymes cited above.

Cytokine induction was determined under ex vivo stimulation of human whole blood cell cultures with LP and the examined EP hydrolysate. This method imitates the natural microenvironment of immunocompetent cells and preserves the intercellular communications between the different blood cell populations. It was observed that EP hydrolysate, at a dose of $100 \mu \mathrm{g} / \mathrm{mL}$ was able to induce the secretion of IL- 6 and IL-10 by human whole blood cells (Table 1). It was shown that EP hydrolysate stimulates the blood cells to release the anti-inflammatory IL-10 in amounts comparable to LP used as a positive control. Also, the level of pro-inflammatory IL-6 produced in response to EP hydrolysate was significantly higher compared to the untreated cells, although almost $50 \%$ lower than that observed for LP.

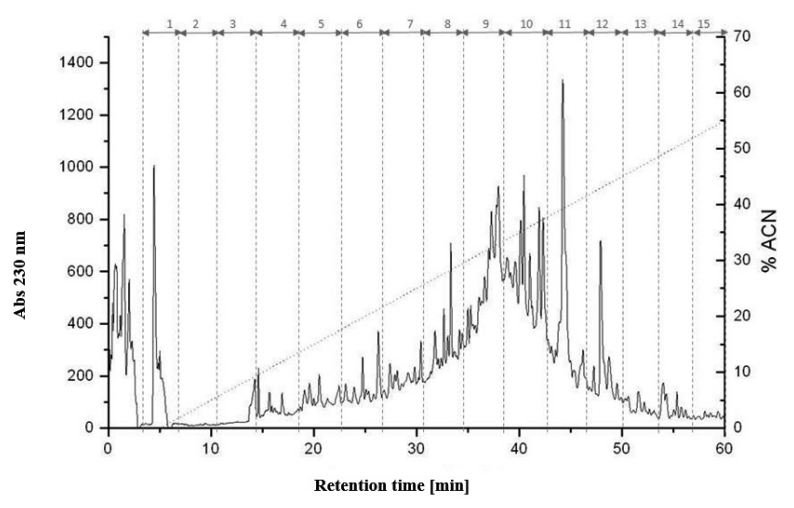

Figure 1. Fractionation of the EP hydrolysate by RP-HPLC. Separation was performed on a Zorbax SemiPrep XDBC18 $(5 \mu \mathrm{m}$, $9.4 \times 250 \mathrm{~mm}$ ) column equilibrated with $0.1 \%$ TFA in water (phase A). Separation conditions: time $-65 \mathrm{~min}$., $\mathrm{T}=30^{\circ} \mathrm{C}$, flow $2 \mathrm{~mL} / \mathrm{min}$, gradient $0-100 \%$ B $(0.1 \%$ TFA in acetonitrile).

In summary, the results obtained here show that EP hydrolysate is a good stimulator of cytokine production in human whole blood cell cultures. Interleukin 6 and Interleukin 10 are produced by Th2 cells and play a crucial role in the regulation of the humoral immune response. The results presented here suggest the possibility of using EP hydrolysate to induce Th2-type cytokines and to regulate the inflammatory reaction.

The isolation and identification of the peptides that determine specific biological activities require the hydrolysate to be fractionated. It is well known that separation of complex mixtures, such as products of enzymatic hydrolysis, is difficult and requires the use of a combination of techniques using the different properties of the peptides (Kamysz et al., 2004). In our research, a biopeptide fractionation procedure based on ultrafiltration and RP- HPLC was used. Initially, the hydrolysate was separated using an ultrafiltration membrane with a cut-off at $30 \mathrm{kDa}$ (Amicon) to remove the enzymes and non-hydrolyzed EP. Subsequently, the hydrolysate was fractionated by RP-HPLC using a ZorbaxSemiPrep XDBC18 column $(5 \mu \mathrm{m}, 9.4 \times 250 \mathrm{~mm})$. This method is regarded as a standard and the most effective of the procedures used in the isolation of proteins and peptides. The main advantage of RP-HPLC is that it allows the separation of even very small fragments of proteins with similar

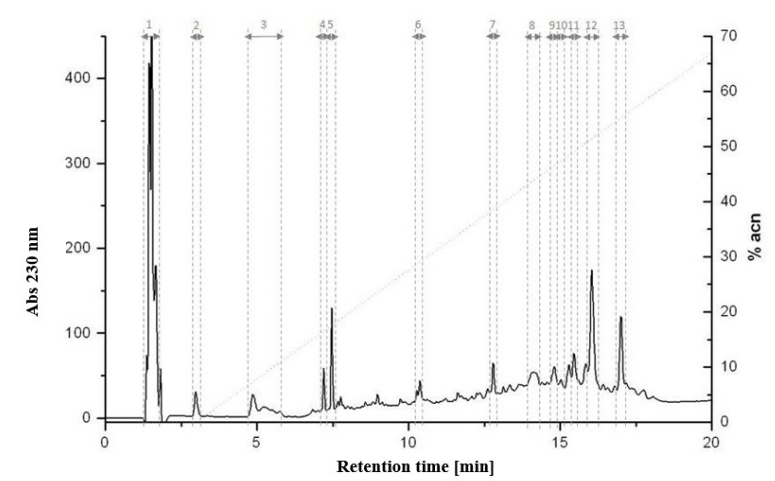

Figure 2. The isolation of peptides from fraction number 3 by RP-HPLC.

The sample was loaded onto a Zorbax XDB-C18 Agilent (50 x 1.8 $\mathrm{mm}$ ) column equilibrated with $0.1 \%$ TFA in water (phase A). Separation conditions: time $-15 \mathrm{~min}$., $\mathrm{T}=30^{\circ} \mathrm{C}$, flow $1 \mathrm{~mL} / \mathrm{min}$, gradient $0-100 \%$ B (0.1\% TFA in acetonitrile). 
a)

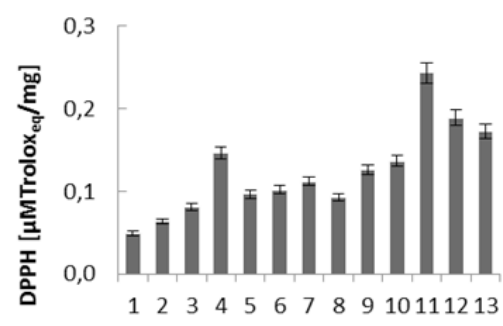

c)

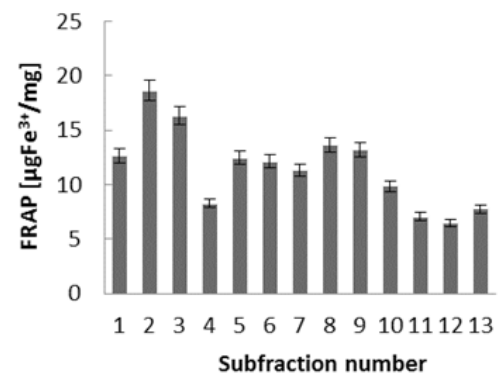

b)

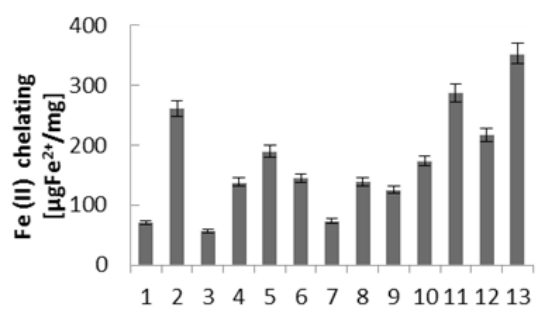

d)

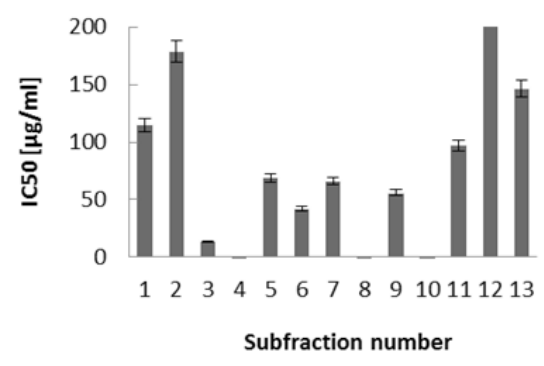

Figure 3. The biological activity of peptide subfractions collected during the chromatography process of fraction number 3. (a) the DPPH free radical scavenging ability; (b) the ability to chelate Fe (II), (c) FRAP; (d) ACE inhibitory activity.

molecular weights and only slightly different amino acid sequences. As a result of RP-HPLC separation, 15 peptide fractions of different hydrophobicity were obtained (Fig. 1). The results show that all of them exhibited antioxidant activity at different levels, but in all cases they were lower than for the initial hydrolysate (Table 2). Similar observations have been described by other researchers, highlighting that in some cases the purification of hydrolysates leads to a loss of their antioxidant activity, which frequently is a result of the entire system of interactions consisting of peptides and free amino acids (Li et al., 2007). However, the highest antioxidant activity, especially a DPPH radical scavenging activity of 0.16 $\mu \mathrm{M}$ Trolox $_{\mathrm{eg}} / \mathrm{mg}$, as well as ferric reducing antioxidant power (12.22 $\mu \mathrm{g} \mathrm{Fe} \mathrm{Fe}^{2+} / \mathrm{mg}$ ) and ferrous chelating (111.9 $\mu \mathrm{g} \mathrm{Fe}^{2+} / \mathrm{mg}$ ) power, was revealed by fraction number 3 (Table 2). This fraction was subjected to further purification using RP-HPLC on a Zorbax $\mathrm{XDB}_{18}$ column $(1.8 \mu \mathrm{m}, 4.6 \times 50 \mathrm{~mm}$ ) (Fig. 2). As a result of this separation step, 13 peptide subfractions were obtained and then were tested for both, the antioxidant and ACE inhibitory activities (Fig. 3).

Four of the obtained subfractions (4, 11, 12, 13) showed higher or similar ability to scavenge free radicals in relation to fraction number 3 , in the range of 0.15 to $0.24 \mu \mathrm{M}$ Trolox $_{\mathrm{eq}} / \mathrm{mg}$. Evaluation of the reducing power (FRAP) revealed the highest value (from 13.2 to $18.6 \mu \mathrm{g}$ $\mathrm{Fe}^{2+} / \mathrm{mg}$ ) in the case of subfractions 2, 3, 8 and 9. Ten of thirteen of the obtained subfractions showed a significantly higher ability to chelate iron (II) than fraction no. 3 , in the range of $125.5-353.7 \mu \mathrm{g} \mathrm{Fe} \mathrm{Fe}^{2+} / \mathrm{mg}$.

Food proteins, especially egg proteins, are a rich source of ACE inhibitory peptides (Majumder \& Wu, 2011). The ability to release ACE inhibitory peptides by $Y$. lipolytica serine protease was also analyzed. The obtained subfractions exhibited ACE inhibitory activity at $\mathrm{IC}_{50}$ values in the range from 13.7 to $1229.1 \mu \mathrm{g} /$ $\mathrm{mL}$. Subfractions number $3\left(\mathrm{IC}_{50}=13.7 \mu \mathrm{g} / \mathrm{mL}\right)$ and 6
$\left(\mathrm{IC}_{50}=42.1 \mu \mathrm{g} / \mathrm{mL}\right.$ ) were the strongest ACE inhibitors. In a previous work, the effects of enzymatic modification of egg white protein by-product (EP) on biological properties were assessed by treatment with Neutrase. The EP hydrolysate, obtained at a technical scale, had an in vitro ACE inhibitory effect of $\mathrm{IC}_{50}=257.4 \mu \mathrm{g} / \mathrm{mL}$ (Pokora et al., 2013).

Peptide subfractions showing the highest biological activity were identified using MALDI-TOF/MS and the Mascot Search Results database. The representative MALDI-ToF/MS spectra are shown in Fig. 4. These analyses showed that the subfractions were mostly mixtures of at least two peptides with sequences corresponding to the hen egg proteins, containing from 2 to 19 amino acid residues (Table 3).

Subfractions 5, 6 and 13 were homogeneous peptides corresponding to ovalbumin fragments with the sequences: VGS (f 343-354), GV (f 349-350) and YQIGLFRVASMASEKM (f 212-228), respectively. Analysis of peptide subfractions 11,12 , and 13 showed that they were mixtures of several peptides. The identification of parent ions by MALDI/TOF/MS revealed the presence of three peptides in subfraction 11: VLDRTWPPAP, TEAMKRALALIDS, and GGVGVPGGLGVPGVVQPGV, corresponding to the fragments of chicken myosin, chicken vinculin, and chicken elastin, respectively (Fig. 4). In subfraction 12, only fragments of ovalbumin with sequences RFDKLPGFGDSIEAQ (f 59-72), KMKILELPFASGTM (f 227-240), and LELPAFASGTM (f 231-240) were identified. Subfraction 2 contained two peptides, DTALGHVI and SSGGAGTPPPA, corresponding to the fragment of the integrator complex subunit 10 and HMX1 homeobox protein, respectively.

The amino acid sequence and composition constitute the main factor determining the bioactivity of the peptides (Danquah \& Agyei, 2012). The hydrophobic properties of peptides play a significant role in their antioxidant activity, particularly in the ability to scavenge 
free radicals and in their reducing power (FRAP). The presence of such amino acid residues as $G, A, V, I, L$, $\mathrm{P}, \mathrm{Y}, \mathrm{M}, \mathrm{H}$, or $\mathrm{W}$ in the peptide sequence denotes high antioxidant properties (Wang et al., 2009). Hydrophobic amino acids are present in the sequences of peptides identified in subfractions 11, 12 and 13, which can result in their high DPPH radicals scavenging capacity, at 0.24 , 0.19 , and $0.17 \mu \mathrm{M}$ Trolox $_{\mathrm{eq}} / \mathrm{mg}$, respectively. Moreover,

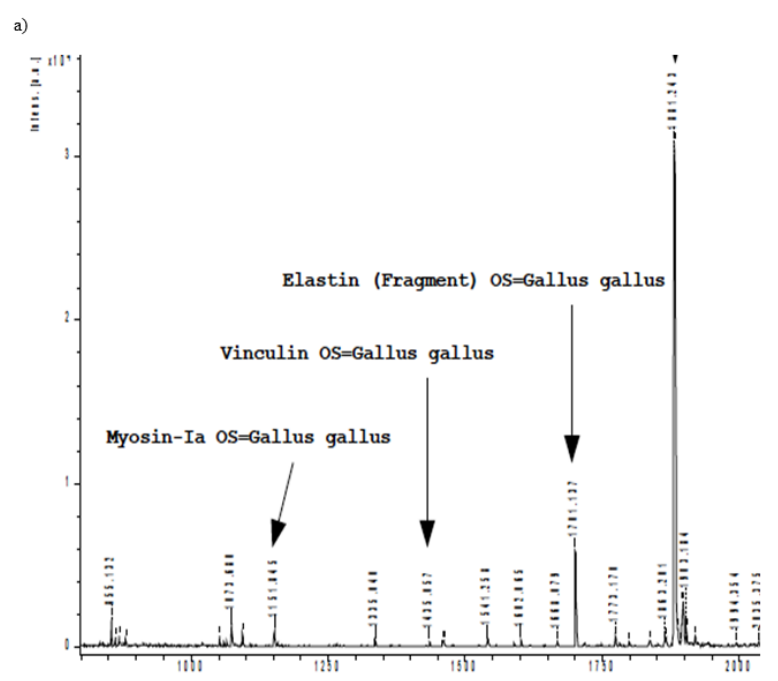

b) the presence of indole, phenol, or imidazole groups (W, $\mathrm{Y}, \mathrm{H})$ in the side chain, as the donors of hydrogen ions, also enhances the antioxidant activity of the peptides (Ajibola et al., 2011). Guo et al. (2009) had reported that strong antioxidant activity is also determined by the $\mathrm{N}$ terminal location of the $\mathrm{L}, \mathrm{I}, \mathrm{V}, \mathrm{K}$, and $\mathrm{A}$ residues in the peptide chain. This may explain the activity of several peptide fractions in which peptides with particularly longer chains were identified, e.g. KMKILELPFASGTM, LELPAFASGTM, and VLDRTWPPAP.

The ability to chelate divalent cations of metal ions is related to the presence in the peptide sequence of branched chain amino acids, such as E, Q, L, R, D, H, and $\mathrm{T}$. The side chains of these amino acids can react with metal ions and thereby inactivate their pro-oxidant action. The presence of such amino acids may explain the highest iron ion chelating activity of subfractions 11 and 13. Amino acid sequence analysis of these subfractions has demonstrated the presence of peptides containing glutamic acid, aspartic acid, glutamine, lysine, and threonine. Elias et al. (2008) pointed out the location of branched chain amino acids in the sequence as an important factor in the chelating activity of peptides and proteins. It is particularly advantageous if they are exposed on the surface of the protein or at the ends of the peptide chains. Such a structure is characteristic for the peptides TEAMKRALALID, LELPAFASGTM, and DTALGHVI, identified in subfractions 11,12 , and 2 , respectively.

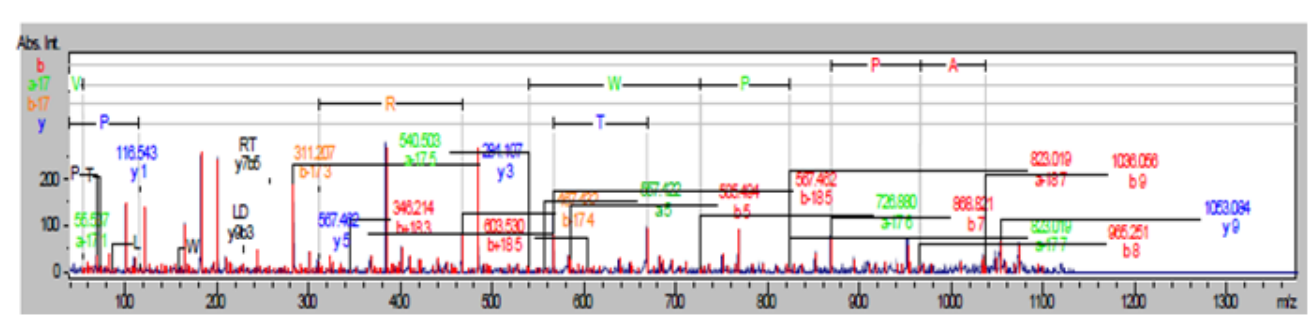

c)

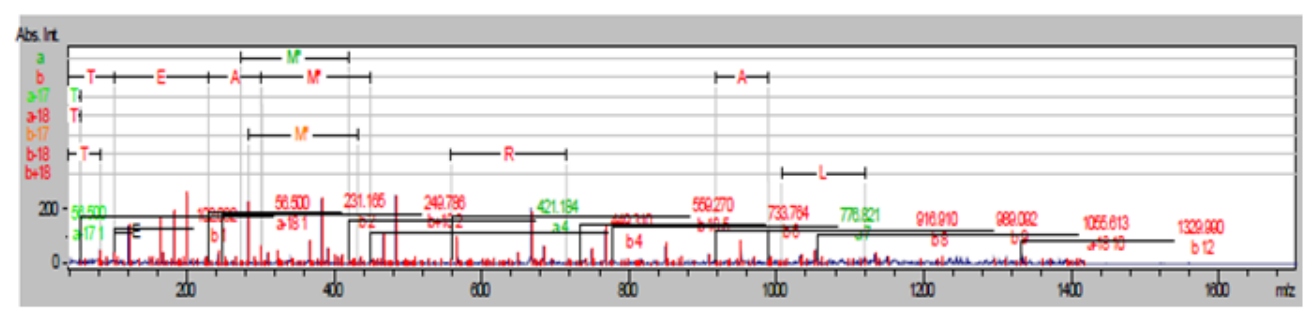

d)

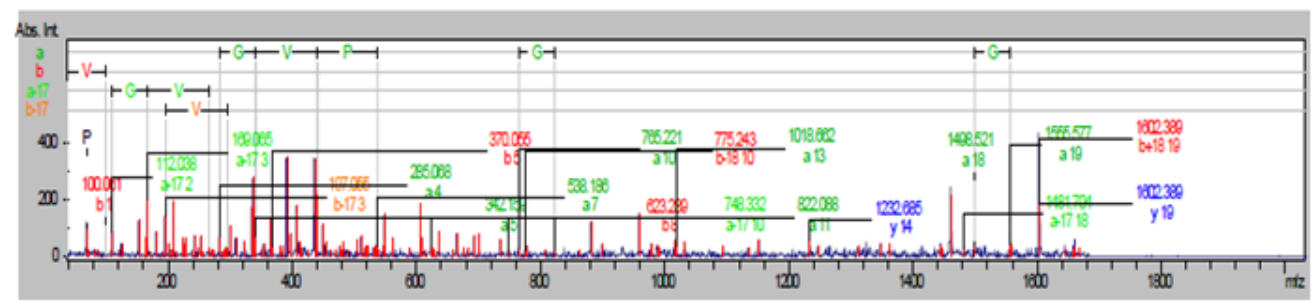

Figure 4. Peptide identification by MALDI-TOF-MS mapping.

(a) representative MALDI-TOF-MS spectra of subfraction 11; (b-d) spectra of selected fragment ions, (b) chicken myosin peptide - VLDRTWPPAP, (c) chicken vinculin peptide - TEAMKRALALIDS, (d) chicken elastin peptide - GGVGVPGGLGVPGVVQPGV. 
Table 3. Identification of peptide fragments in the selected peptide subfractions.

\begin{tabular}{llll}
\hline $\begin{array}{l}\text { Subfraction } \\
\text { number }\end{array}$ & $\begin{array}{l}\text { Peptide sequence } \\
\text { MALDI TOF/ MS }\end{array}$ & Biological activity & Homolog protein/ UniProtKB/SwissProt \\
\hline 2 & $\begin{array}{l}\text { DTALGHVI [1]; } \\
\text { SSGGAGTPPPA [2] }\end{array}$ & $\begin{array}{l}\text { FRAP; } \\
\text { Fe (II) chelating }\end{array}$ & $\begin{array}{l}\text { [1] - fragment subunit 10 of the chicken egg complex } \\
\text { integration } \\
{[2]-\text { HMX1 homeobox protein fragment }}\end{array}$ \\
\hline 5 & VGS & ACE inhibitor & ovalbumin, (f 343-345)
\end{tabular}

GV ACE inhibitor ovalbumin, (f 349-350)

11

$\begin{array}{ll}\text { VLDRTWPPAP [1]; } & \text { DPPH scavenging, } \\ \text { TEAMKRALALIDS [2]; } & \text { FRAP; } \\ \text { GGVGVPGGLGVPGVVQ-PGV [3] } & \text { Fe (II) chelating }\end{array}$

[1] - fragment of chicken myosin,

[2] - fragment of chicken vinculin

[3] - fragment of chicken elastin;
[1] - ovalbumin, (f 59-72)

[2] - ovalbumin, (f 227-240)

[3] - ovalbumin, (f 231-240)
A common feature of several of the identified peptides is the presence of repeating amino acid residues located in adjacent positions in the peptide structure; e.g. the dipeptide and tripeptide sequences of serine, glycine, proline, or valine in the peptides SSGGAGTPPPA and GGVGVPGGLGVPGVVQPGV. According to Siow \& Gan (2013), such peptide fragments have a higher biological activity than sequences containing such amino acid appearing only once.

Food proteins are a rich source of peptide inhibitors of the angiotensin-converting enzyme (ACE), an enzyme which plays a crucial role in the regulation of blood pressure. In our study, a strong ACE inhibitory effect was exerted by subfractions $3,6,7$, and 5 . Among them, MS analysis of subfractions 5 and 6 gave positive results, indicating that they are homogenous and composed of short chain peptides VGS and GV, respectively. According to other authors, to generate an inhibition effect, ACE reacts with peptides composed of specific amino acid residues, typical for $\mathrm{C}$ - and $\mathrm{N}$ ends of the ACE inhibitors. Hydrophobic amino acids, especially those with aliphatic chains, such as G, L, I and $\mathrm{V}$, are typical for the $\mathrm{N}$ - end of peptides (Iwaniak et al. 2014). The presence $V$ and $G$ may explain the high antihypertensive effect of peptides from EP. Furthermore, the most potent ACE inhibitors contain hydrophobic amino acid residues at their C-terminal tripeptide sequence (Karamać et al., 2005). In our study, subfraction 11, composed of the VLDRTWPPAP, TEAMKRALALID, and GGVGVPGGLGVPGV'VQPGV peptides, exerted a significant ACE-inhibitory activity. The first peptide contains two proline residues while the third contains proline, glycine, and valine at the C-terminal tripeptide sequence, which may be crucial for the ACE-inhibitory activity.
The biopeptides obtained in our study have not been previously described by other authors. However, peptides having some sequence similarity are known. An example would be the sequences of VG and PG with potential ability of ACE inhibition, identified in in silico studies with bovine lactoferrin, as well as the VECYGPNRPQF peptide isolated from a pepsin hydrolysate of algae protein. There are also known peptides with antihypertensive activity, such as SY, NY, SF, and NF, whose characteristic feature is the presence of serine or asparagine at the N-terminus (Kumar et al., 2010).

\section{CONCLUSIONS}

Tests were made of the proteolytic properties of the non-conventional serine protease from $Y$. lipolytica toward egg white protein by-product (EP) following the ethanol extraction of lysozyme and cystatin, and its ability to release bioactive peptides. This serine protease had caused an extensive degradation of EP $(38 \%)$. The obtained hydrolysate exhibited antioxidant and cytokine inducing activity. The purification and characterization of the EP-derived peptides by ultrafiltration, RP-HPLC, and MALDI ToF mass spectrometry led to detection of the following peptide sequences DTALGHVI, SSGGAGTPPPA, VGS, GV, VLDRTWPPAP, TEAMKRALALIDS, GGVGVPGGLGVPGVVQPGV, RFDKLPGFGDSIEAQ, KMKILELPFASGTM, LELPAFASGTM, and YQIGLFRVASMASEKM. The obtained peptide fractions exerted an ACE-inhibitory activity and an antioxidant activity reflected as the DPPH free radical scavenging ability, ability to chelate Fe (II), and a ferric reducing activity (FRAP). A new application of the serine protease from $Y$. lipolytica yeast in the production of bioactive peptides was shown. 


\section{Conflict of interest}

All of the authors who took part in this study declare that they have nothing to disclose regarding competing interests or funding from industry with respect to this manuscript.

\section{Acknowledgements}

This research was funded by the project "Innovative technologies in the production of bio-preparations based on new generation eggs", Innovative Economy Operational Programme Priority 1.3.1, thematic area "Bio", co-financed by the European Union through the European Regional Development Fund within the Innovative Economy Operational Programme, 2007-2013.

This project was also supported by the Wrocław Centre of Biotechnology programme and the Leading $\mathrm{Na}$ tional Research Centre (KNOW), 2014-2018.

\section{REFERENCES}

Ajibola CF, Fashakin JB, Fagbemi TN, Aluko RE (2011) Effect of peptide size on antioxidant properties of african yam bean seed (Sphenostylis stenocarpa) protein hydrolysate fractions. Int J Mol Sci 12: 6685-6702. http://dx.doi.org/10.3390/ijms12106685

Babij K, Dąbrowska A, Szołtysik M, Pokora M, Szmyt A, Zambrowicz A, Chrzanowska J (2013) Ocena podatności białek serwatkowych na działanie zewnątrzkomórkowych proteaz drożdży Yarrowia lipolytica. Acta Sci Pol Biotechnol 12: 5-17

Babij K, Dabrowska A, Szołtysik M, Pokora M, Zambrowicz A, Kupczyński R, Chrzanowska J (2014) Use of enzymatic hydrolysis of whey proteins for the preparation of peptides with an antioxidant activity. Pryem Chem 8: 1000-1005

Bagewadi ZK, Garg SD, Deshnur PB, Shetti NS, Banne AA (2011) Production dynamics of extracellular alkaline protease from Neisseria sps isolated from soil. Biotechnol Bioinf Bioeng 1: 483-493

Benzie IF, Strain JJ (1996) The ferric reducing ability of plasma (FRAP) as a measure of "antioxidant power": the FRAP assay. Anal Biochem 239: 70-76

Booth FW, Roberts CK, Laye MJ (2012). Lack of exercise is a major cause of chronic diseases. Compr Physiol 2: 1143-1211

Carr D (2002) The handbook of analysis and purification of peptides and proteins by Reversed phase HPLC. Vydac G ed, 3rd Technocal Support Group. USA

Danquah MK, Agyei D (2012) Pharmaceutical applications of bioactive peptides. $O A$ Biotechnol 1: $1-7$

Dávalos A, Bartolomé B, López-Fandiño R (2004) Antioxidant activity of peptides derived from egg white proteins by enzymatic hydrolysis. J Food Prot 67: 1939-1944

Dhurway KS, Ramdas M, Tiwari A, Malviya SN, Yadav M (2012) Production, purification and characterization of protease from "Aspergillus oryzae". Discov Biotechnol 1: 1-6

Dominguez A, Fermiñan E, Gaillardin C (2000) Yarrowia lipolytica: an organism amenable to genetic manipulation as a model for analyzing dimorphism in fungi. In Dimorphism in buman pathogenic and apathogenic yeasts. Ernst JF, Schmidt A eds, 151-172, Basel: Karger

Elias RJ, Kellerby SS, Decker E (2008) Antioxidant activity of proteins and peptides. Crit Rev Food Sci Nut 48: 430-441. http://dx.doi. org/10.1080/10408390701425615

Fujita H, Yokoyama K, Yoshikawa M (2000) Classification and antihypertensive activity of angiotensin I-converting enzyme inhibitory peptides derived from food proteins. J Food Sci 65: 564-569. http:// dx.doi.org/10.1111/j.1365-2621.2000.tb16049.x

Gardini F, Tofalo R, Belletti N, Iucci L, Suzzi G, Torriani S, Guerzoni ME, Lanciotti R (2006) Characterization of yeasts involved in the ripening of Pecorino Crotonese cheese. Food Microbiol 23: 641-648

Glover DJ, McEwen RK, Thomas CR, Young TW (1997) pH- regulated expression of the acid and alkaline extracellular proteases Yarrowia lipolytica. Microbiol 143: 3045-3054

Guerzoni ME, Lanciotti R, Maachetti R (1993) Survey of the physiological properties of the most frequent Yeats associated with commercial chilled foods. Int J Food Microbiol 17: 329-341

Guo H, Kouzuma Y, Yonekura M (2009) Structures and properties of antioxidative peptides derived from royal jelly protein. Food Chem 113: 238-245. http://dx.doi.org/10.1016/j.foodchem.2008.06.081

Iwaniak A, Minkiewicz P, Darewicz M (2014) Food- originating ACE inhibitors, including antihypertensive peptides, as preventive food components in blood pressure reduction. Compr Rev Fod Sci F 13: 114-134
Kamysz W, Okrój M, Łempicka E, Ossowski T, Lukasiak J (2004) Fast and efficient purification of synthetic peptides by solid-phase extraction. Acta Chromat 14: 180-186

Karamać M, Flaczyk E, Janitha PK, Wanasundara PD, Amarowicz R (2005) Angiotensin I-converting enzyme (ACE) inhibitory activity of hydrolysates obtained from muscle food industry by-products - a short report. Pol J Food Nutr Sci 14: 133-137

Kumar R, Kumar A, Sharma R, Baruwa A (2010) Pharmacological review on Natural ACE inhibitors. Der Pharm Lett 2: 273-293

Li B, Chen F, Wang X, Ji B, Wu Y (2007) Isolation and identification of antioxidative peptides from porcine collagen hydrolysate by consecutive chromatography and electrospray ionization-mass spectrometry. Food Chem 102: 1135-1143

Lowry OH, Rosebrough NJ, Farr AL, Randall RJ (1951) Protein measurement with the Folin phenol reagent. I Biol Chem 193: 265-275

Majumder K, Wu J (2011) Purification and characterization of angiotensin I converting enzyme (ACE) inhibitory peptides derived from enzymatic hydrolysate of ovotransferrin. Food Chem 126: 1614-1619

Miguel M, Recio I, Gomez-Ruiz JA, Ramos M, Lopez-Fandino R (2004) Angiotensin I-converting enzyme inhibitory activity of peptides derived from egg white proteins by enzymatic hydrolysis. $J$ Food Prot 67: 1914-1920

Nel S, Labuschagne M, Albertyn J(2009) Advances in gene expression in non-convesional yeasts, Yarrowia lipolytica. In Yeast Biotech: Div. App. Satyanarayana T, Kunze G eds, 381-384. Springer Science+ Buisness Media B.V.

Ogrydziak DM (1988) Production of alkaline extracellular protease by Yarrowia lipolytica. Crit Rev Biotechnol 8: 177-187. http://dx.doi. org $/ 10.1111 /$ j.1567-1364.2012.00846.x

Ogrydziak DM, Nicaud JM (2012) Characterization of Yarrowia lipolytica XPR2 multi-copy strains over-producing alkaline extracellular protease - a system for rapidly increasing secretory pathway cargo loads. Yeast Res 12: 938-948

Pokora M, Eckert E, Zambrowicz A, Bobak L, Szołtysik M, Dąbrowska A, Chrzanowska J, Polanowski A, Trziszka T (2013) Biological and functional properties of proteolytic enzyme-modified egg protein by-products. Food Sci Nutr 1: 184-195. http://dx.doi. org/10.1002/fsn 3.27

Pokora M, Szołtysik M, Dabrowska A, Chrzanowska J, Trziszka T (2010) Application of noncommercial proteolytic enzymes in hydrolysis of egg-white proteins. Acta Sci Pol Biotechnol 9: 17-24

Ray A (2012) Protease enzyme- potential industrial scope. Int J Tech 2: $1-5$

Rohrbach MS, Williams EB, Rolstad RA (1981) Purification and substrate specificity of bovine angiotensin-converting enzyme. $J$ Biol Chem 256: 225-230

Rywińska A, Tomaszewska L, Rymowicz W (2013) Erythritol biosynthesis by Yarrowia lipolytica yeast under various culture conditions. Afr I Microbiol Res 7: 3511-3516

Sathyavrathan P, Kavitha M (2013) Production of alkaline protease from Bacillus licheniformis (NCIM 2044) and media optimisation for enhanced enzyme production. Int J Chem Tech Res 5: 550-553

Schaafsma G (2009) Safety of protein hydrolysates, fractions thereof and bioactive peptides in human nutrition. Europ J Clin Nut 63: 1161-11618. http://dx.doi.org/10.1038/ejcn.2009.56

Silvestre MPC (1996) Review of methods for the analysis of protein hydrolysates. Food Chem 60: 263-271

Siow H-L, Gan C-Y (2013) Extraction of antioxidative and antihypertensive bioactive peptides from Parkia speciosa seeds. Food Chem 141: 3435-3442. http://dx.doi.org/10.1016/j.foodchem.2013.06.030

Sokołowska A, Kubiak A, Trziszka T, Polanowski A (2007) Rapid one step separation of proteinaceous agents of antimicrobial activity from hen's egg white. Pol J Food Nutr Sci 57: 499-502

Srinu Babu G, Shiva Kiran RR, Lokeswari, N, Jaya Raju, K (2007) Optimization of protease production from Aspergillus oryzae sp. using box-behnken experimental design. E-J Chem 4: 145-153

Szołtysik M, Niedbalska J, Dąbrowska A, Kupczyński R, Zambrowicz A, Pokora M, Połomska X, Chrzanowska, J, Wojtatowicz M (2012) Use of enzymatic hydrolysis of casein for the preparation of peptides with antioxidative activity. Pryem Chem 91: 1-6

Vasantha ST, Subramanian AT (2012) Optimization of cultural conditions for the production of an extra-cellular protease by Pseudomonas species. Int Curr Pharma J 2: 1-6

Vermelho AB, Supuran CT, Guisan JM (2012) Microbial enzyme: applications in industry and in bioremediation. En₹ Res ID 980681. http://dx.doi.org/10.1155/2012/980681

Wang X-S, Tang C-H, Chen L, Yang X-Q (2009) Characterization and antioxidant properties of hemp protein hydrolysates obtained with Neutrase ${ }^{\circledR}$. Food Technol Biotechnol 47: 428-434

Xu X, Katayama S, Mine Y (2007) Antioxidant activity of tryptic digests of hen egg yolk phosvitin. J Sci Food Agric 87: 2604-2608. http://dx.doi.org/10.1002/jsfa.3015

Yen GC, Chen HY (1995) Antioxidant activity of various tea extracts in relation to their antimutagenicity. I Agric Food Chem 43: 27-32

Zabłocka A, Sosnowska A, Urbaniak A, Janusz M, Polanowski A (2014) Peptides accompanying chicken egg yolk IgY alternative 
methods of isolation and immunoregulatory activity. Food Funct 5: 724-733

Zambrowicz A, Pokora M, Eckert E, Chrzanowska J, Szołtysik M, Dąbrowska A, Chrzanowska J, Trziszka T (2013) Antioxidative peptides derived from denaturated egg white protein. Ital J Food Sci 25 169-178

Zambrowicz A, Eckert E, Pokora M, Bobak L, Dąbrowska A, Szołtysik M, Trziszka, Chrzanowska J (2015a) Antioxidant and antidiabetic activities of peptides isolated from a hydrolysate of an egg-yolk protein by-product prepared with a proteinase from Asian pumpkin (Cucurbita ficifolia). RSC Adv 5: 10460-10467. http://dx.doi. org/10.1039/C4RA12943A

Zambrowicz A, Pokora M, Setner B, Dąbrowska A, Szołtysik M, Babij K, Szewczuk Z, Trziszka T, Lubec, G, Chrzanowska J (2015b) Multifunctional peptides derived from an egg yolk protein hydrolysate: isolation and characterization. Amino Acids 47: 369-380. http:// dx.doi.org/10.1007/s00726-014-1869-x

Zinjarde SS (2014) Food related applications of Yarrowia lipolytica. Food Chem 152: 1-10. http://dx.doi.org/10.1016/j.foodchem.2013.11.117 